\author{
Leszek Butowski \\ Uczelnia Vistula, Warsaw \\ Józef Piłsudski University of Physical Education in Warsaw \\ Faculty of Tourism and Recreation \\ leszek.butowski@wp.pl
}

\title{
TOURISM - AN ACADEMIC DISCIPLINE (DISCURSIVE ARTICLE)
}

\begin{abstract}
The article discusses the main methodological dilemmas connected with tourism as a field of academic research. The first part presents tourism as an area of interest in various academic disciplines. The second is a critical discussion on multidisciplinary and interdisciplinary approaches to the study of tourism. The third features an analysis of the methodological standpoints concerning possibilities for the autonomy of tourism as an academic discipline. The summary proposes a model of development for tourism studies aimed at the autonomy of academic tourism.
\end{abstract}

Key words: tourism, academic discipline, paradigm, academic unity.

\section{INTRODUCTION}

The purpose of the author is to try to determine the direction of methodological progress in the academic study of tourism - in the context of the possibility of autonomy (on a theoretical basis) of academic tourism. This issue has been presented against discussion in both Polish and foreign academic literature that has been going on for many years (and is still far from finding final conclusions).

The article consists of three parts. The first, introductory one, points to tourism as an area of interest to various academic disciplines. To that end, it implements a research scheme which combines LISZEWSKI's analytic approach (2010) with the dominant academic aspects of tourism suggested by PRZECŁAWSKI (2010). The result is a list of academic disciplines for which tourism is an important object of research. The second part undertakes a discussion of multidisciplinary and interdisciplinary studies of tourism. The author focuses attention on a critical description of the contribution of both approaches to creating a theoretical basis for tourism as an academic field. The third, the main part, provides an analysis of the methodological standpoints concerning possibilities for the separation of tourism as a distinct academic discipline. The discussion is enclosed between the paradigm approach (KUHN 1968) and an evolutionary one which recognizes the unity of all academic disciplines (BERNSTEIN 1991, ECHTER, JAMAL 1997).

The final part of the article is a summary. The analysis has given grounds to put forward two hypo- thetical models of development (in the methodological sense) of tourism studies aimed at distinguishing of a new discipline.

\section{TOURISM AS AN AREA OF INTEREST FOR VARIOUS ACADEMIC DISCIPLINES}

The growth of interest in tourism among representatives from many academic disciplines, corresponding to particular aspects of tourism, has progressed together with the development of tourism as a multidimensional and complex phenomenon of psychological, social, economic, spatial and cultural character (PRZECEAWSKI 2010). From an historical point of view, the first to study tourism were geographers and economists, and later sociologists. It seems that these are still in the lead. At the same time, they are being increasingly complemented by others, including anthropology, ecology, physical culture, psychology and others.

The idea of a chronological development in the academic study of tourism was presented by JAFARI (1992). He distinguished four phases in sequence but each does not supplant the others. In the last phase, named by the author 'Knowledge-Based Platform', stress is put on the need for systematic research on tourism. 
$\mathrm{T}$ a b l e 1. Tourism as an area of interest to various academic disciplines in the context of the subject of tourism research

\begin{tabular}{|c|c|c|c|}
\hline $\begin{array}{l}\text { The subject } \\
\text { of tourism } \\
\text { research }\end{array}$ & $\begin{array}{l}\text { Domina- } \\
\text { ting } \\
\text { aspects }\end{array}$ & $\begin{array}{l}\text { Fields } \\
\text { of study }\end{array}$ & $\begin{array}{c}\text { Main academic } \\
\text { disciplines }\end{array}$ \\
\hline \multirow{9}{*}{$\begin{array}{l}\text { The tourist as } \\
\text { the subject } \\
\text { and the } \\
\text { originator of } \\
\text { the tourism } \\
\text { phenomenon }\end{array}$} & \multirow{9}{*}{$\begin{array}{l}\text { Psycho- } \\
\text { logical } \\
\text { (psycho- } \\
\text { physical), } \\
\text { cultural }\end{array}$} & The economy & \begin{tabular}{|l|} 
Economics \\
\end{tabular} \\
\hline & & \multirow{4}{*}{ Humanities } & Philosophy \\
\hline & & & Pedagogy \\
\hline & & & \begin{tabular}{|l|} 
Psychology \\
\end{tabular} \\
\hline & & & \begin{tabular}{|l|} 
Sociology \\
\end{tabular} \\
\hline & & $\begin{array}{l}\begin{array}{l}\text { The study of } \\
\text { physical culture }\end{array} \\
\end{array}$ & Physical culture \\
\hline & & Medical sciences & Medicine \\
\hline & & \begin{tabular}{|l|} 
Legal studies \\
\end{tabular} & Law \\
\hline & & $\begin{array}{l}\text { Theological } \\
\text { studies }\end{array}$ & Theology \\
\hline \multirow{7}{*}{$\begin{array}{l}\text { Tourism } \\
\text { movement }\end{array}$} & \multirow{7}{*}{$\begin{array}{l}\text { Economic, } \\
\text { spatial }\end{array}$} & & Economy \\
\hline & & Economics & $\begin{array}{l}\text { Management } \\
\text { studies }\end{array}$ \\
\hline & & Humanities & Sociology \\
\hline & & Tumanties & History \\
\hline & & Earth sciences & Geography \\
\hline & & \begin{tabular}{|l} 
Technical \\
studies \\
\end{tabular} & Transport \\
\hline & & \begin{tabular}{|l|} 
Theology \\
\end{tabular} & \begin{tabular}{|l|} 
Theological studies \\
\end{tabular} \\
\hline \multirow{7}{*}{$\begin{array}{l}\text { Tourism } \\
\text { space - } \\
\text { destinations } \\
\text { and transit } \\
\text { areas }\end{array}$} & \multirow{7}{*}{$\begin{array}{l}\text { Spatial } \\
\text { (environ- } \\
\text { mental), } \\
\text { eco- } \\
\text { nomical }\end{array}$} & \begin{tabular}{|l|l}
$\begin{array}{l}\text { Biological } \\
\text { sciences }\end{array}$ \\
\end{tabular} & Ecology \\
\hline & & & Economy \\
\hline & & Economics & $\begin{array}{l}\text { Management } \\
\text { studies }\end{array}$ \\
\hline & & \begin{tabular}{|l|} 
Earth sciences \\
\end{tabular} & Geography \\
\hline & & $\begin{array}{l}\text { Agricultural } \\
\text { sciences }\end{array}$ & $\begin{array}{l}\text { Environmental } \\
\text { management }\end{array}$ \\
\hline & & Technical & $\begin{array}{l}\text { Architecture and } \\
\text { urban planning }\end{array}$ \\
\hline & & studies & \begin{tabular}{|l}
$\begin{array}{l}\text { Building } \\
\text { engineering }\end{array}$ \\
\end{tabular} \\
\hline \multirow{10}{*}{$\begin{array}{l}\text { Tourism } \\
\text { activity - } \\
\text { ways and } \\
\text { forms of } \\
\text { cultivating } \\
\text { tourism }\end{array}$} & \multirow{10}{*}{$\begin{array}{l}\text { Cultural, } \\
\text { psycho- } \\
\text { logical } \\
\text { (psycho- } \\
\text { physical) }\end{array}$} & & Economics \\
\hline & & Economics & $\begin{array}{l}\text { Management } \\
\text { studies }\end{array}$ \\
\hline & & & Cultural studies \\
\hline & & & \begin{tabular}{|l|} 
Pedagogics \\
\end{tabular} \\
\hline & & Humanities & \begin{tabular}{|l|} 
Psychology \\
\end{tabular} \\
\hline & & Humanities & \begin{tabular}{|l} 
Sociology \\
\end{tabular} \\
\hline & & & \begin{tabular}{|l}
$\begin{array}{l}\text { Management } \\
\text { studies }\end{array}$ \\
\end{tabular} \\
\hline & & \begin{tabular}{|l} 
Medical studies \\
\end{tabular} & Medicine \\
\hline & & $\begin{array}{l}\text { The study of } \\
\text { physical culture }\end{array}$ & Physical culture \\
\hline & & Earth sciences & Geography \\
\hline \multirow{12}{*}{$\begin{array}{l}\text { Effects and } \\
\text { consequences } \\
\text { of tourism } \\
\text { activity - for } \\
\text { tourists, for } \\
\text { organizers, } \\
\text { for the } \\
\text { community } \\
\text { hosting } \\
\text { tourists, for } \\
\text { the natural } \\
\text { and socio- } \\
\text { cultural } \\
\text { environment }\end{array}$} & \multirow{12}{*}{$\begin{array}{l}\text { Economic, } \\
\text { cultural, } \\
\text { spatial, } \\
\text { social }\end{array}$} & \begin{tabular}{|l} 
Biological \\
sciences
\end{tabular} & Ecology \\
\hline & & \multirow[b]{2}{*}{ Ecor } & Economics \\
\hline & & & $\begin{array}{l}\text { Management } \\
\text { studies }\end{array}$ \\
\hline & & \multirow{6}{*}{ Humanities } & \begin{tabular}{|l|} 
Ethnology \\
\end{tabular} \\
\hline & & & Culture \\
\hline & & & History \\
\hline & & & $\begin{array}{l}\text { Management } \\
\text { studies }\end{array}$ \\
\hline & & & \begin{tabular}{|l|} 
Political studies \\
\end{tabular} \\
\hline & & & Sociology \\
\hline & & \multirow[t]{2}{*}{ Legal studies } & $\begin{array}{l}\text { Administration } \\
\text { studies }\end{array}$ \\
\hline & & & Law \\
\hline & & Earth sciences & Geography \\
\hline
\end{tabular}

S o u r c e: author based on LISZEWSKI (2010).
In the Polish literature of the past two decades numerous books devoted to the methodological basis of tourism studies conducted within various disciplines of academic can be found. Among them are monographs edited by WINIARSKI (1999, 2003), NOWAKOWSKI (2001), PRZYBYSZEWSKA-GUDELIS, GRABISZEWSKI (2002), GOŁEMBSKI (2003, 2008), KAZIMIERCZAK (2004), MAIK et al. (2005), WiNIARSKI, ALEJZIAK (2005), NOWAKOWSKI, PRZYDZIAE (2006), KRUPA, BILIŃSKI (2006), WINIARSKI (2008). Among authors concerned with this issue (primarily from the perspective of particular disciplines) one should name from geography WARSZYŃSKA, JACKOWSKI (1978), KRZYMOWSKA-KOSTROWICKA (1997), KOWALCZYK (2001 and later editions), LISZEWSKI (2003, 2010); from economics NOWAKOWSKA (2003), BOSIACKI (2005), GOŁEMBSKI (2001), GAWORECKI (1994 and later editions); from sociology and other humanities, and from the study of physical culture: WOŹNIAK $(1995,2004)$, PRZECEAWSKI (1997, 2010), ŁOBOŻEWICZ (2001), ZDEBSKI (2003), PODEMSKI (2004), KAZIMIERCZAK (2005, 2010), MAZURKIEWICZ (2009).

In order to prepare a basis for further discussion the author has made an attempt to define the range of interest in tourism shown by various academic disciplines ${ }^{1}$. To this end, he implemented the scheme proposed by LISZEWSKI (2010) according to whom the phenomenon of tourism, treated as a system of elements (sets) consists of: 1) tourists - the subject of the phenomenon; 2) the process of movement (tourism 'migration'); 3) destinations and transit locations (tourism space); 4) tourism activity (its forms and how to cultivate them); 5) effects and consequences of the migration and staying of the tourist at each stage of the process. These elements have been juxtaposed with the dominating academic aspects (psychological, social, economic, spatial and cultural) named by PRZECEAWSKI (2010). Keeping in mind the fact that the results of the analysis are simplified (as a consequence of the complexity of the phenomenon of tourism itself as well as the 'stiffness' of the formal division into fields and academic disciplines²), they have been presented in Table 1.

\section{THE STUDY OF TOURISM - MULTIDISCIPLINARY AND INTERDISCIPLINARY APPROACHES}

Multidsciplinary and interdisciplinary approaches are often used to dealing with something that belongs to an area of interest of various disciplines. The former occurs when a common issue is researched within different disciplines producing separate results. The latter applies when a given issue is researched on the 
basis of different disciplines, but the result is meant to be integrated (CHOJNICKI 2005). In such a context tourism appears to be especially predestined to be dealt with using both approaches. This was underlined by such as JAFARI, RITCHI (1981) who named economics, sociology, psychology, geography and anthropology as the main disciplines engaged in tourism studies. This list was extended by JAFARI, AASER (1988) to 15 disciplines on the basis of an analysis of $\mathrm{PhD}$ theses in the US. This statement is confirmed also by the number of doctoral and postdoctoral theses on tourism within various academic disciplines in Poland (Table 2).

$\mathrm{T} \mathrm{a} \mathrm{b} \mathrm{l} \mathrm{e} \mathrm{2.} \mathrm{Doctoral} \mathrm{and} \mathrm{post-doctoral} \mathrm{on} \mathrm{tourism} \mathrm{according}$ to academic discipline in the period 2001-010

\begin{tabular}{|c|c|c|c|c|c|}
\hline $\begin{array}{l}\text { Academic } \\
\text { fields }\end{array}$ & $\begin{array}{l}\text { Academic } \\
\text { discipline }\end{array}$ & $\begin{array}{c}\text { Doctor- } \\
\text { ates }\end{array}$ & $\begin{array}{l}\text { Habili- } \\
\text { tation }\end{array}$ & \multicolumn{2}{|c|}{ Total } \\
\hline $\begin{array}{l}\text { Biological } \\
\text { sciences }\end{array}$ & Biology & 1 & 0 & 1 & $0.54 \%$ \\
\hline \multirow[t]{2}{*}{ Economics } & $\begin{array}{l}\text { Management } \\
\text { studies }\end{array}$ & 18 & 1 & \multirow[t]{2}{*}{73} & \multirow[t]{2}{*}{$39.67 \%$} \\
\hline & Economics & 50 & 4 & & \\
\hline \multirow{6}{*}{ Humanities } & Political studies & 2 & 1 & \multirow{6}{*}{17} & \multirow{6}{*}{$9.24 \%$} \\
\hline & Sociology & 5 & - & & \\
\hline & Linguistics & 3 & - & & \\
\hline & History & 3 & - & & \\
\hline & Culture & 1 & - & & \\
\hline & Pedagogics & 2 & - & & \\
\hline $\begin{array}{l}\text { Studies of } \\
\text { physical culture }\end{array}$ & Physical culture & 22 & 2 & 24 & $13.04 \%$ \\
\hline Forest science & Forestry & 3 & - & 3 & $1.63 \%$ \\
\hline \multirow{2}{*}{ Earth sciences } & Geography & 42 & 3 & \multirow{2}{*}{47} & \multirow{2}{*}{$25.54 \%$} \\
\hline & Geology & 2 & - & & \\
\hline Legal studies & Law & 1 & - & 1 & $0.54 \%$ \\
\hline \multirow{4}{*}{$\begin{array}{l}\text { Agricultural } \\
\text { science }\end{array}$} & $\begin{array}{l}\text { Environmental } \\
\text { management }\end{array}$ & 3 & 1 & \multirow{4}{*}{13} & \multirow{4}{*}{$7.07 \%$} \\
\hline & Agronomy & 7 & - & & \\
\hline & $\begin{array}{l}\text { Food technology } \\
\text { and nutrition }\end{array}$ & 1 & - & & \\
\hline & Zootechnics & 1 & - & & \\
\hline \multirow{3}{*}{$\begin{array}{l}\text { Technical } \\
\text { studies }\end{array}$} & $\begin{array}{l}\text { Architecture and } \\
\text { urban planning }\end{array}$ & 2 & 1 & \multirow{3}{*}{5} & \multirow{3}{*}{$2.72 \%$} \\
\hline & \begin{tabular}{|l} 
Building \\
engineering
\end{tabular} & 1 & - & & \\
\hline & $\begin{array}{l}\text { Geodesy and } \\
\text { cartography }\end{array}$ & 1 & - & & \\
\hline \multicolumn{2}{|l|}{ Total } & 171 & 13 & 184 & 100.00 \\
\hline
\end{tabular}

S o u r c e: author - based on database www.nauka-polska.pl.

At the same time, it seems that most academics support (or at least declare to do so) the interdisciplinary study of tourism. Among them are the following who have placed their hopes on this type of study: THEUNS (1986), LEIPER (1990), GOŁEMBSKI (2003), ALEJZIAK (2003), VUKOVIĆ (2005). According to BOSIACKI (2005) the ground-breaking moment of the development of academic research into Polish tourism was the implementation of the interdisciplinary 'Central Research Programme' entitled 'Tourism as a factor in socio-economic development' in 1986-1990.

Taking into consideration the necessity of conducting interdisciplinary studies of tourism GRABURN, JAFARI (1991) among others, and in the Polish literature, MAIK (2002) and MAIK, PRZYBECKA-MAIK (2005), present a less optimistic evaluation. The latter believe that at present multidisciplinary research still dominates which results in a lack of integration in the research field, the lack of a coherent conception of research, and a low degree of issue integration. Simultaneously, the postulated interdisciplinary approach is still underdeveloped and faces numerous obstacles. This opinion seems to be confirmed by dispersion and the disappointing cooperation between those institutions concerned with tourism studies.

Agreeing that tourism arouses the interest of numerous academic disciplines (within the meaning of the 'material object'3), it can be seen that they simultaneously define the 'formal object' of their investigation according to different aspects. This leads to difficulties in the research integration especially in a multidisciplinary approach, but also in an interdisciplinary one. It seems that such a situation is one of the most significant barriers hindering methodological progress. One interesting way of overcoming that barrier is proposed on a theoretical basis by MACIOEEK (2002). He postulates the creation of a socalled tourism studies 'boss' whose task would be to synthesize the partial results coming from different disciplines. Until such a state of affairs the real dominance of interdisciplinary studies over multidisciplinary studies will not be achieved. The same author underlines that such a science should be formed basing on the reflection on the tourism object of the ex interno type instead of the commonly applied ex interno type. In other words, it should be formed by adjusting its formal subject to those aspects of tourism that refer to its substance.

Considering the issue of the methodological and factual integration of interdisciplinary tourism studies (in the context of cooperation between theory and practice) the opposite opinion is represented by MAIK (2002). This author believes that interdisciplinary cooperation should take into consideration the individuality of every discipline and simultaneously reinforce the integrity of tourism studies. It should be acknowledged that this view is quite controversial since it contains two postulates which are difficult to reconcile. 
To sum up this analysis of the issue of interdisciplinarity and multidisciplinarity, it should be noted that most academics do not question the need for developing research of the interdisciplinary type. They stress the potential benefits that can be reaped thanks to this kind of academic activity. On the other hand, when analysing the current state of affairs, the real scope for implementing interdisciplinary research in tourism is to be doubted. It seems that, as far as tourism is concerned, the multidisciplinary approach still dominates.

Another issue is the contribution of interdisciplinary studies to the theoretical and methodological bases of tourism as a field of study. It seems that after the first, enthusiastic period when academics thought that such an approach would provide revolutionary progress in the theory of tourism, we are now dealing with more balanced evaluations. Advantage of methodological progress that occurred in other disciplines, which could have been expected from interdisciplinary research, failed to be taken. Many authors believe that tourism still lacks solid theory (DANN, NASH, PEARCE 1988, VUKONIC 2005, AIREY 20024, 2005). Such opinions give foundation to the conclusion that expected progress has not occurred and it is doubtful that this could happen in the short term. At the same time, views are appearing that there is a need to form a discipline (for the time being rather meta-disciplinary) which, based on a precisely defined and agreed substance of tourism (the object of its studies), would be able to integrate, from a methodological and factual position, the contributions of academic disciplines dealing with this field at the moment.

\section{TOURISM AS AN ACADEMIC DISCIPLINE - METHODOLOGICAL DILEMMAS}

Academics concerned with tourism often present totally different opinions upon the issue of the possibility of the autonomy of tourism as a separate academic discipline (ALEJZIAK 2003, p. 159-162). These differences are based on various methodological premises and often also on institutional ones (CHŁOPECKI 2005). Internationally, strong proponents of the autonomy of tourism as an academic discipline (being in a minority) include JOVICIĆ (1988), COMIC (1989) and LEIPER (2000). Among Polish academics, the group of authors gathered around the departments (institutes) of tourism functioning within universities of physical education (ŁOBOŻEWICZ 2001, SIKORA 2001, KAZIMIERCZAK 2005) are proponents. One of the arguments they bring up is the recognition of similar rights for physical culture. In opposition is a relatively large group from traditional disciplines who think that there is no sufficient methodological basis to form tourism studies. At the same time they advocate conducting interdisciplinary research on tourism (DANN, NASH, PEARCE 1988, JAFARI 1989, TRIBE 1997, WiTT, BROKE, Buckley 1991, PEARCE, Butler 1993, SZuberT-ZARZECZNY 2001, GOŁEMBSKI 2003). Among academics who strongly stress a need for the improvement of theory in tourism are those from the humanities (WOŹNIAK 1995, 2005, PODEMSKI 2004, ALEJZIAK 2008). They discern methodological weaknesses in this field but simultaneously point to the necessity of qualitative changes in previous approaches without which academic progress will not be possible. In this context the evolution of the standpoints of some academics is interesting (ROGOZIŃSKI 1975, 1985, LISZEWSKI 1994, 2010).

One of more fierce opponents of the recognition of tourism as a separate discipline is TRIBE (1997), the author of a well-known article entitled 'The Indiscipline of Tourism' in which he indicates the 'undisciplinarity' of tourism. Tribe's views met with the opposition of an Australian academic Leiper (2000) whose argument with Tribe was published in the Annals of Tourism Research. He tried to indicate (mostly on the basis of empirical premises) that tourism is on the right path to academic independence.

ALEJZIAK (2003, pp. 162-164) points out that one of the basic conditions of the development and autonomy of tourism studies is their theoretical, methodological and practical integration. Unfortunately, the gauntlet is still too rarely picked up, in particular by tourism academics. Thus, in the opinion of CHOJNICKI (2005), who conducted an analysis from the theoretical-methodological point of view, is particularly valuable. He recognized that studies on tourism (at the current stage of development) are at a proto-level which does not fulfil all the requirements expected. At the same time, he believes that it has an empirical character. It is mainly a social science, but of a complex type (it also includes the natural sciences) as well as an applied discipline. The same author, when analysing the object of academic interest in this field, sees it on two levels of complexity. He refers to 1) tourism as a specific phenomenon alongside other specific phenomena; and 2) tourism as an economic, social and spatial phenomenon. At the same time, he stresses that only the former approach can constitute a basis for the autonomy of tourism. The latter leads to a multidisciplinary conception. This view agrees with the opinion of MACIOŁEK (2002), who stresses that the autonomy of tourism studies (from the methodological point of view) will not be possible until the essence of tourism, and on this basis the 'formal object' 
of studies expressing the constitutive (specific) features of this field, are defined.

If Chojnicki's opinion about the protoacademic character of tourism is to be agreed, it should also be agreed that tourism is at the pre-paradigmatic stage (PEARCE 1993). In this context one further fundamental condition should be added to the list for recognition of tourism as a discipline: the need for the implementation, probably by way of a Kuhnian academic revolution ${ }^{5}$, of a convincing paradigm - a defined academic model of tourism.

One who accepts this is SZUBERT-ZARZECZNY (2001), who believes that the implementation of a paradigm will enable integration of knowledge about tourism, presently dispersed, and thus it will facilitate defining its object ${ }^{6}$. ALEJZIAK (2008), in turn, conducted an analysis of general paradigms of social science in the context of the possibility for their implementation in tourism studies. To sum up, one can state that the paradigmatic approach contains logically and chronologically ordered stages of 1) multidisciplinary research; 2) interdisciplinary research; 3) qualitative changes (Kuhn's academic revolution) that lead to the implementation of a new paradigm; 4) the formation of new autonomous tourism studies. This process has been schematically presented in the Fig 1.

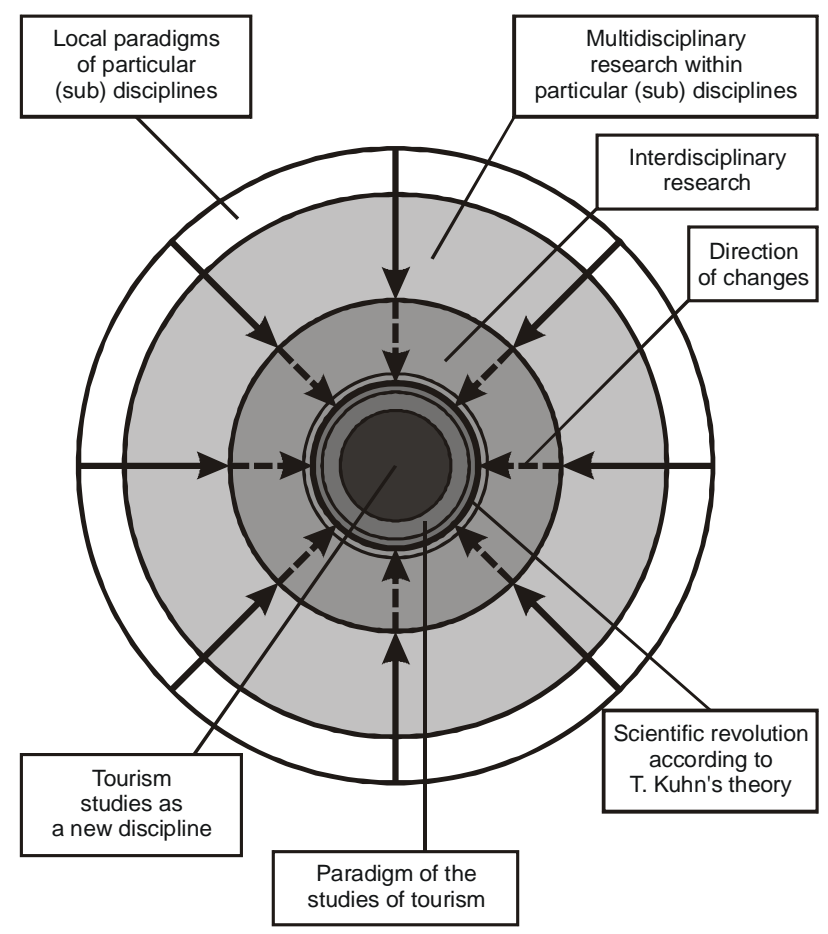

Fig. 1. Autonomy in the study of tourism according to the paradigmatic approach Sou r c e: author

Exactly the opposite view is represented by ECHTNER, JAMAL (1997). They argue that because of the attachment of representatives of different disciplines (concerned with tourism) to their own paradigms it is very unlikely that a common academic model for this field will be adopted. At the same time, these authors incline to the model suggested by BERNSTEIN (1991) which assumes the unity of knowledge ${ }^{7}$. In this context the previous interdisciplinary barriers cease to be that significant and the complexity of tourism starts to appear an asset leading in a direct ${ }^{8}$ way to the formation of an autonomous discipline. In conclusion they suggest five directions leading to the autonomy of tourism studies: 1) creating theoretical bases for the new discipline; 2) implementation of a holistic and integrated approach; 3) focusing on interdisciplinary research; 4) explaining theory and methodology; 5) taking advantage of various methodological traditions (positivist and interpretative).

A diagram of such an approach, called evolutionary, has been presented in Fig. 2.

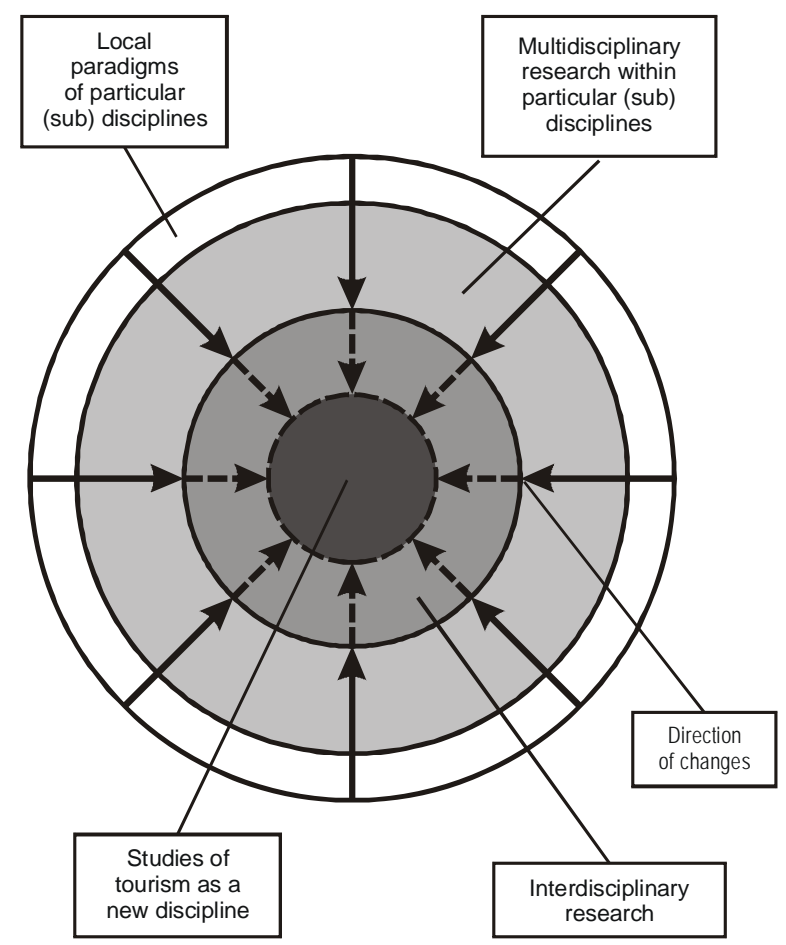

Fig. 2. Autonomy of the study of tourism according to the evolutionary approach S our ce: author

\section{SUMMARY AND CONCLUSIONS}

Tourism, as a mass and global phenomenon, which at one and the same time is complex and multi-aspectual, is an area of interest of numerous academic disciplines. This field, due to its heterogeneity, appears to be particularly predestined to multi-disciplinary studies, 
especially interdisciplinary research. On the other hand, it seems that the heterogeneity of the research object of tourism constitutes a basic obstacle for methodological and theoretical development. This makes the autonomy of tourism studies impossible and creates a barrier restraining further study and understanding of the phenomenon itself.

Despite the above-mentioned problems research into tourism will definitely continue to be carried out. The article puts forward the proposal that its development (in the methodological sense) leading to the autonomy of tourism studies, can proceed in one of two ways: according to the paradigmatic model or the evolutionary one (Fig. 3). It is difficult to decide which one will finally dominate. It seems that the paradigmatic model is more distinct. The condition that must be fulfilled in order for it to exist is a fundamental change in awareness; there must be agreement to apply a common model and forego attachment to the 'local paradigms' of particular disciplines. In turn, a chance for the evolutionary approach may lay in the development of interdisciplinary research. According to many this constitutes the best tool for understanding the complex processes occurring in the contemporary world.

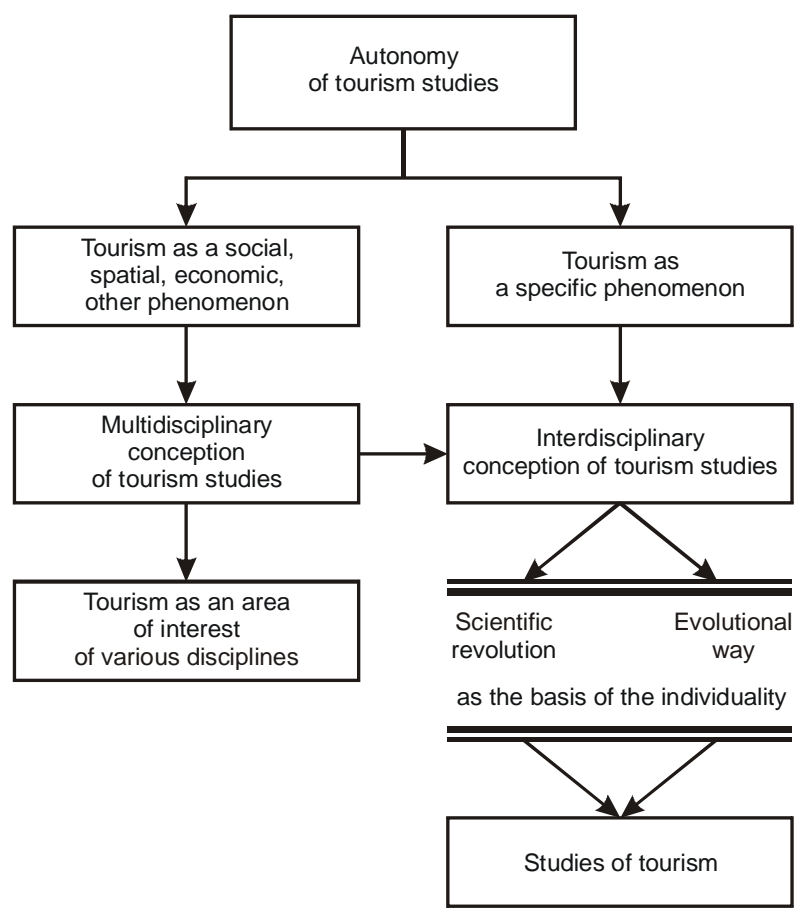

Fig. 3. Hypothetical process of the autonomy of tourism studies Source: author

A possible consequence (but unlikely in a long term perspective) is the intensification of multidisciplinary research (at the expense of the interdisciplinary approach), in which tourism will still be considered the domain of particular disciplines. Surely, such an option would not contribute to the methodological development in the field of tourism studies as a specific phenomenon. It is also likely that it would not contribute much to research in those disciplines.

\section{FOOTNOTES}

1 Such attempts were made also by e.g. GOŁEMBSKI (2003) and MARAK, WYRZYKOWSKI (2009).

2 For order's sake and due to comparative-historical purposes (relevant later in the article) the author adopted the division into disciplines coherent with the Polish administrative classification.

${ }^{3}$ A 'material object' is what is being studied and a 'formal object' is the aspect of research on the 'material object'. This means that many disciplines have a common 'material object' but they differ in the 'formal object'. It can even be stated that a 'formal object' and not a 'material object' distinguishes a discipline in terms of 'objects' (MACIOŁEK 2002, p. 22).

${ }^{4}$ Airey brings up the idea of a tourism area life cycle by BUTLER (1980) as a rare example of the implementation of an interdisciplinary approach in order to build a theoretical model which is an important contribution to the theory of tourism. In addition the interdisciplinary idea of tourism attractiveness by Polish academic Prof. ROGALEWSKI (1974) can be mentioned here.

5 Such an approach agrees with the paradigmatic model of science of KUHN (1968). However, it should be noted that the theory of science also accepts a so-called hypothetically-deductive (falsificational) model that stems from critical rationalism. It indicates the role of criticism in the development of science. According to this idea scientific theories (paradigms) should not in any way monopolize knowledge, but on the contrary they should enable continous verification by means of empirical research (POPPER 1973, DETEL 1995).

6 The author, in order to support her argument, gives an example of a local paradigm defined in terms of the economics of tourism.

7 Bernstein questions the methodological division of sciences into natural science (Naturwissenschaften) and the humanities (Geisteswissenschaften).

${ }^{8}$ In this approach a reference can be seen to the linear model of science development by Popper.

\section{BIBLIOGRAPHY}

AIREY, D., 2002, Growth and Change in Tourism Education, [in:] B. Vukonic, N. Cavlek (eds.), Rethinking Education and Training for Tourism, University of Zagreb, pp. 13-22.

AIREY, D., 2005, Badania, wiedza i edukacja: turystyka na rozdrożach, [in:] R. Winiarski, W. Alejziak (eds.), Turystyka w badaniach naukowych, AWF w Krakowie, WSIiZ w Rzeszowie, pp. 251-261.

ALEJZIAK, W., 2003, Perspektywy i kierunki rozwoju badań naukowych nad turystyka, [in:] G. Gołembski (ed.), 2003, Kierunki rozwoju badan naukowych w turystyce, Akademia Ekonomiczna w Poznaniu, PWN, Warszawa, pp. 231-248.

ALEJZIAK, W., 2005, Aktualny stan oraz perspektywy rozwoju badań naukowych nad turystyka, [in:] R. Winiarski, W. Alejziak (eds), Turystyka w badaniach naukowych, AWF w Krakowie, WSIiZ w Rzeszowie, Kraków-Rzeszów, pp. 275-298.

ALEJZIAK, W., 2008, Podstawowe paradygmaty i podejścia badawcze w studiach nad turystyka, [in:] G. Gołembski (ed.), Nowe trendy rozwoju turystyki, Wyd. PWSZ, Sulechów, pp. 13-25. 
BERNSTEIN, R., 1991, Beyond Objectivism and Relativism: Science, Hermeneutics and Praxis, University of Pennsylvania, Philadelphia.

BOSIACKI, S., 2005, Ekonomiczne problemy turystyki jako przedmiot badań naukowych w Polsce, [in:] R. Winiarski, W. Alejziak (eds.), Turystyka w badaniach naukowych, AWF Kraków, WSZiI w Rzeszowie, pp. 189-202.

BUTLER, R.W., 1980, The concept of a tourist area cycle of evolution: implication for managment of resources, 'The Canadian Geographer', vol. 24, No. 1, pp. 348-354.

CHŁOPECKI, J., 2005, Turystologia jako dyscyplina naukowa, [in:] R. Winiarski, W. Alejziak (eds.), Turystyka w badaniach naukowych, AWF Kraków, WSIiZ w Rzeszowie.

CHOJNICKI, Z., 2005, Charakter i sytuacja nauki o turystyce - rozważania metodologiczne, Zeszyty Naukowe Wyższej Szkoły Gospodarki, Bydgoszcz, 'Turystyka i Rekreacja', t. 3, pp. 11-23.

COMIC, D., 1989, Tourism as a Subject of Philosophical Reflection, 'Revue de Tourisme', No. 44, pp. 6-13.

DANN, G., NASH, D., PEARCE, P., 1988, Methodology in Tourism Research, 'Annals of Tourism Research', No. 18, pp. 155-169.

DETEL, W., 1995, Nauka, [in:] E. Martens, H. Schnädelbach (eds.), Filozofia. Podstawowe pytania, Wiedza Powszechna, Warszawa, pp. 197-242.

ECHTNER, C.M, JAMAL, T.B., 1997, The Disciplinary Dilemma of Tourism Studies, 'Annals of Tourism Research', No. 24, pp. 868-883.

GOŁEMBSKI, G., 2003, Turystyka jako czynnik integrujacy badania naukowe, [in:] G. Gołembski (ed.), 2003, Kierunki rozwoju badań naukowych w turystyce, Akademia Ekonomiczna w Poznaniu, PWN, Warszawa, pp. 11-22.

GOŁEMBSKI, G. (ed), 2008, Nowe trendy rozwoju turystyki, Wyd. PWSZ, Sulechów.

GRABURN, N., JAFARI, J. (eds.), 1991, Tourism social science, 'Annals of Tourism Research', Sp. Issue.

JAFARI, J., 1989, Structure of Tourism, [in:] Tourism Marketing and Management Handbook, S.F. Witt, L. Moutinho (eds.), Prentice Hall, London, pp. 437-442.

JAFARI, J., 1992, Towards Tourism Mitigation, The Freedom of Travelling in the Year 2000 - AIEST, vol. 34, St-Call.

JAFARI, J., AASER D., 1988, Tourism as a Subject of Doctoral Dissertation, 'Annals of Tourism Research', No. 15, pp. 407-429.

JAFARI, J., RITCHIE B., 1981, Towards a Framework of Tourism Education: Problems and Prospects, 'Annals of Tourism Research', No. 8, pp. 13-34.

Jovicic, Z., 1988, A Plea for Tourismological Theory and Methodology, 'Revue de Tourisme', No. 43, pp. 2-5.

KAZIMIERCZAK, M. (red.), 2004, Turystyka $w$ humanistycznej perspektywie, AWF, Poznań.

KAZIMIERCZAK, M., 2005, Filozofia turystyki a integracja nauk o turystyce, Akademia Ekonomiczna w Poznaniu, PWN, Warszawa.

KAZIMIERCZAK, M., 2010, O autonomii nauk w turystyce, [in:] S. Tanaś (ed.), Nauka $i$ dydaktyka $w$ turystyce $i$ rekreacji, Łódzkie Towarzystwo Naukowe, Łódź, pp. 11-20.

KOWALCZYK, A., 2001, Geografia turyzmu, PWN, Warszawa 2001.

KRUPA, J., BILIŃSKI, J., 2006, Turystyka w badaniach naukowych: prace przyrodnicze $i$ humanistyczne, WSIiZ w Rzeszowie, Rzeszów.

KRZYMOWSKA-KOSTROWICKA, A., 1997, Geoekologia turystyki i wypoczynku, PWN, Warszawa.

KUHN, T.S., 1968, Struktura rewolucji naukowych, PWN, Warszawa.

LEIPER, N., 1990, Tourism Systems: An Interdyscyplinary Study, Occasion Papers, 2, Massey University.
LEIPER, N., 2000, An Emerging Discipline, 'Annals of Tourism Research', No. 27, pp. 805-809.

LISZEWSKI, S., 1994, Perspektywy badań naukowych w zakresie turystyki w Polsce $w$ najbliższym dziesięcioleciu, 'Problemy Turystyki', nr 3/4, pp. 105-111.

LISZEWSKI, S., 2003, Wkład geografii w rozwój turystyki w Polsce, [in:] G. Gołembski (ed.), 2003, Kierunki rozwoju badań naukowych $w$ turystyce, AE w Poznaniu, PWN, Warszawa, pp. 111-121.

LISZEWSKI, S., 2010, Nauka czy nauki o turystyce, 'Turyzm', t. 20, z. 2, pp. 37-45.

ŁOBOŻEWICZ, T., 2001, Miejsce turystyki w naukach o kulturze fizycznej, Zeszyty Naukowe AWF w Krakowie, nr 31, p. 13-20.

MACIOŁEK, R., 2002, Osobliwości metodologiczne badań nad turystyka, Zeszyty Naukowe Wyższej Szkoły Turystyki i Hotelarstwa w Bydgoszczy, nr 2, pp. 17-26.

MAIK, W., 2002, Strategia wspótpracy nauki i praktyki w zakresie planowania rozwoju turystyki, [in:] R. Przybyszewska-Gudelis, M. Grabiszewski (eds.), Partnerstwo nauki i praktyki w turystyce - fakty, intencje, potrzeby rozwoju, Zeszyty Naukowe, nr 2, Wyższa Pomorska Szkoła Turystyki i Hotelarstwa w Bydgoszczy, pp. 41-48.

MAIK, W., MARCINIAK, K., PALICH, P. (red.), 2005, Teoria i praktyka $w$ turystyce, Zeszyty Naukowe, nr 2, Wyższa Szkoła Gospodarki w Bydgoszczy.

MAIK, W., PRZYBECKA-MAIK, M., 2005, Główne czynniki i płaszczyzny integracyjne w naukach o turystyce, Zeszyty Naukowe Wyższej Szkoły Gospodarki Bydgoszcz, Turystyka i Rekreacja, t. 3, pp. 25-32.

MARAK, J., WYRZYKOWSKI, J., 2009, Turystyka jako przedmiot interdyscyplinarnych badań naukowych, Zeszyty Naukowe Uniwersytetu Szczecińskiego, nr 567, 'Ekonomiczne Problemy Turystyki', z. 12, pp. $165-180$.

MAZURKIEWICZ, L., 2009, O przedmiocie turystyki i rekreacji, 'Turystyka i Rekreacja', t. 5, AWF Warszawa, pp. 80-91.

NOWAKOWSKA, A., 2001, (red.), Cele i treści akademickiego ksztatcenia $w$ dziedzinie turystyki $i$ rekreacji, Zeszyty Naukowe, nr 81, AWF w Krakowie.

NOWAKOWSKA, A., 2003, Ekonomika turystyki, [in:] R. Winiarski (ed.), Nauki o turystyce, 'Studia i Monografie', nr 7 (part I), AWF, Kraków, pp. 33-42.

NOWAKOWSKA, A., PRZYDZIAE, M. (eds.), 2006, Turystyka w badaniach naukowych: prace ekonomiczne, WSIiZ w Rzeszowie.

PEARCE, P.L., 1993, Defining tourism Study as a Specialism: A Justification and Implications, TEOROS International, 1, pp. 25-32

PEARCE, P.L., BUTLER R. (eds.), 1993, Tourism Research: Critiques and Challenges, Routledge, London.

PODEMSKI, K., 2004, Socjologia podróży, Wyd. Naukowe UAM, Poznań.

POPPER, K.R., 1973, The Two Faces of Common Sense, [in:] Objective knowledge. An Evolutionary Approach, London.

PRZECŁAWSKI, K., 1997, Etyczne podstawy turystyki, Albis, Kraków.

PRZECŁAWSKI, K., 2010, Człowiek w czasie i przestrzeni, Albis, Kraków.

PRZYBYSZEWSKA-GUDELIS, R., GRABISZEWSKI, M. (eds.), 2002, Partnerstwo nauki i praktyki $w$ turystyce - fakty, intencje, potrzeby rozwoju, Zeszyty Naukowe 2, Wyższa Pomorska Szkoła Turystyki i Hotelarstwa w Bydgoszczy.

ROGALEWSKI, O., 1974, Zagospodarowanie turystyczne, WSiP, Warszawa.

ROGOZIŃSKI, K., 1975, Wprowadzenie do teorii i badań turystyki, 'Nauka Polska', nr 9-10.

ROGOZIŃSKI, K., 1985, Tourism as a Subject of Research and Intergration of of Sciences, 'Problemy Turystyki', nr 4, pp. 7-19. 
Rozporządzenie Ministra Nauki i Szkolnictwa Wyższego z 8 sierpnia 2011 r. w sprawie obszarów wiedzy, dziedzin nauki i sztuki oraz dyscyplin naukowych i artystycznych, Dz.U. 2011, nr 179, poz. 1065.

SIKORA, J., 2001, Potrzeba wyodrębnienia nauk o turystyce, [in:] A. Nowakowska (red.), Cele i treści akademickiego kształcenia $w$ dziedzinie turystyki $i$ rekreacji, Zeszyty Naukowe, nr 81, AWF w Krakowie, pp. 81-83.

SZUBERT-ZARZECZNY, U., 2001, Kilka uwag o potrzebie autonomizacji 'nauki o turystyce', [in:] A. Nowakowska (ed.), Cele i treści akademickiego kształcenia w dziedzinie turystyki i rekreacji, Zeszyty Naukowe, nr 81, AWF w Krakowie, pp. 75-79.

Uchwała Centralnej Komisji ds. Stopni i Tytułów z 24 października 2005 r. w sprawie określenia dziedzin nauki i dziedzin sztuki oraz dyscyplin naukowych i artystycznych, MP, 2005, nr 79, poz. 1120 ze zm.

THEUNS, L., 1986, Priorytety w badaniach turystycznych. Przeglad opinii ekspertów, ze szczególnym uwzględnieniem krajów rozwijajacych sie, 'Problemy Turystyki', nr 1, pp. 48-66.

TRIBE, J., 1997, The Indiscipline of Tourism, 'Annals of Tourism Research', No. 24, pp. 638-654.
Vuković, B., 2005, 1990 - Punkt zwrotny w badaniach nad turystyka europejska, [in:] R. Winiarski, W. Alejziak (eds.), Turystyka w badaniach naukowych, AWF Kraków, WSIiZ w Rzeszowie.

WARSZYŃSKA, J., JACKOWSKI, A., 1978, Podstawy geografii turyzmu, PWN, Warszawa.

WINIARSKI, R., (red.), 1999, 2003, Nauki o turystyce, 'Studia i Monografie', nr 7 (part I i II), AWF, Kraków.

WINIARSKI, R. (red.), 2008, Turystyka w naukach humanistycznych, PWN, Warszawa.

WINIARSKI, R., ALEJZIAK, W. (eds.), 2005, Turystyka w badaniach naukowych, AWF Kraków, WSliZ w Rzeszowie.

WITT, S., BROKE, M., BUCKLEY, P., 1991, The management of International Tourism, Unwin Hyman, London.

WOŹNIAK, A., 1995, Czy potrzebna jest integracja metodologiczna samowiedzy nauk zajmujących się turystyką?, [in:] p. Bosiacki (ed.), Turystyka i rekreacja jako czynnik integracji europejskiej, AWF w Poznaniu, pp. 52-56.

WOŹNIAK, A., 2005, Socjologiczna analiza turystyki - poszukiwanie syntezy, Zeszyty Naukowe Wyższej Szkoły Gospodarki w Bydgoszczy, Turystyka i Rekreacja, t. 3, pp. 45-52.

ZDEBSKI, J., 2003, Psychologia turystyki, [in:] R. Winiarski (ed.), Nauki o turystyce, 'Studia i Monografie', nr 7 (part I), AWF w Krakowie, pp. 55-66. 